\title{
Local Democracy and the Public Services
}

Gunnar Helgi Kristinsson prófessor við félagsvísindadeild H.Í.

1. tbl. 1. árg. 2005

Fræðigreinar 


\section{Abstract}

This article explores the relationship between democratic participation and responsiveness. Data from Icelandic local governments is used to examine the assumptions of three different theories of democracy: the minimalist theory, the theory of party democracy and theories of participatory democracy. No support was found for the minimalist theory that merely the competitive element is sufficient to bring about responsive organisations. Party democracy receives some support in that party membership tends to increase the satisfaction of citizens with their local government. Party members, however, are only a small proportion of the electorate. Direct participation tends to increase the knowledge and satisfaction of the citizens but size and the non-representative nature of activists pose a problem for the theory.

How democratic participation affects the effectiveness of organisations is a surprisingly little researched issue. In Mintzberg's (1983) important guide to the designing of effective organisations there is in fact no democratic type - presumably either because such organizations don't exist or because they are not effective. The existence of local governments (which is a universal feature of modern democratic government) nonetheless, is partly justified by their ability to bring administration closer to the citizens and encouraging participation in local affairs. (Mill 1977; Sharpe 1970; Dabl \& Tufte 1974) We lack, however, understanding of how this should come about.

Political theorists - unlike organizational theorists - often make assumptions about participation and democracy. Classical elitism regards democratic participation as a facade, more or less, and according to Schumpeter's "minimalist" conception of democracy "the electoral mass is incapable of action other than a stampede". (Schumpeter 1976: 283) Pluralists tend to be pessimistic about the prospects for participatory democracy and Dabl (in a passage typical of his early work) claims that "the ignorant and unpropertied masses which Madison and his colleagues so much feared are considerably less active politically than the educated and well to do. By their propensity for political passivity the poor and uneducated disfranchise themselves." (Dabl 1956: 81)

In many European states, the mass party has traditionally been seen as an intermediary between state and society; an orderly and realistic form of mass participation. In the early phases of democratisation the mass parties which were invented on the left spread - through what Duverger terms a process of contagion - over the whole political spectrum because of their greater democratic legitimacy and electoral competitiveness. (Duverger 1964) The decline of the mass parties in recent decades, however, as Katz and Mair point out, has moved them to a stage where "they actually move closer to becoming part of the state, and remain quite a remove from civil society". (Mair 1994: 8) The decline in conventional participation (elections, party organisations) has led to an increasing interest in unconventional methods of participation. In fact, unconventional methods of participation seem capable, to some extent at least, of replacing the more conventional methods as outlets for citizen activity. (Dalton 2002) The problem is that participatory democracy is not a highly developed model of democracy. (Macpherson 1977: 93) In fact, participation may have a "dark side", as Fiorina points out when nonrepresentative groups of citizens have disproportional influence on public decision-making. (Fiorina 1999) The answer to this dilemma is, of course to broaden participation and involve a broader cross-section of the citizenry, but broadening political participation may not be an 
entirely straightforward affair. It is by no means obvious that greater actual participation will necessarily follow from greater opportunities for participation.

Experiments with new forms of participation, nonetheless, seem a tempting response to several of the changes which many Western European countries have been facing, as Peter John points out:

In tandem with the need to raise the visibility and effectiveness of local leadership are cross European attempts to renew democratic mechanisms. Local governments have realized they have neglected the citizens in their experiments with NPM [New Public Management]. This response does not just amount to the almost desperate attempts to raise local political participation in the UK. But there has been a more wide-ranging set of experiments that not only reform the institutions of representative democracy, but also experiment with new forms of local participation, such as referenda, citizen juries, deliberative polls and electronic democracy. ... The diverse set of experiments is the final element to the emerging system of governance that seeks to compensate for the loss of clear lines of democratic accountability. (John 2001: 157)

While normative political theory can obviously not be verified empirically, normative scholars frequently make assumptions about man and society which can. Schumpeter, for example, assumes that electoral competition is the mechanism which ensures responsiveness. This means that if we can find cases where both competition and responsiveness can be operationalised, we have the means for testing his assumptions.

In this paper we examine the impact of participation on democratic responsiveness in the context of Icelandic local government. Icelandic local governments have been undergoing an incremental process of change during the last 10-15 years guided by the theory that with the increasing size of local government units there follow considerable economies of scale and the greater welfare of the population. The number of local governments has gone down by almost balf, from close to 200 in the beginning of the 1990s to 101 at present. Further amalgamations are planned and if the Ministry of Social Affairs has its way the number should go below 50 before long. The large number of small local government units in Iceland allows us to examine local participation under conditions which are rare in other countries.

$W$ shall examine in the first place if electoral competition increases the responsiveness of local governments, along the lines suggested by Schumpeter and the minimalist school of democracy. Secondly we investigate to what extent - if any - party organisations and participation in parties increase the responsiveness of local governments along the lines suggested by theories of party democracy. Finally we shall see if participatory democracy creates a more responsive local government, along the lines suggested by participatory theories of democracy.

\section{Fragmented local government}

Local governments in Iceland are uniquely small. Reykjavik is the largest, with 114 thousand inhabitants, which is close to $40 \%$ of the total population. Four other communes have over ten thousand inhabitants but the great majority of Icelandic local governments contain far smaller populations. Out of 101 communes, 96 have less than ten thousand inhabitants and in fact the majority 
of communes have less than five hundred inhabitants. 14 have less than a hundred and the smallest at present is Mjóifjörour with 38 inhabitants. The vast majority of the population, however, resides in the larger communes - only one out of three Icelanders live in communes with less than ten thousand inhabitants (even if these include $95 \%$ of the communes). ${ }^{1}$

The major policy problem at the local government level has for decades been considered the large number of small and relatively weak local governments. (Eythórsson 1998) The system of local government was to a large extent imported from Denmark in 1872 although the basic units were formed in accordance with the older system of "hreppar" dating from the tenth century. The secondary level - the "amt" - was abolished in 1907 and an intermediate level, - the "sýsla" - in 1987. Thus, today, Iceland operates a single layer of local governments (sveitarstjorn). Compared to the Scandinavian countries, Icelandic local governments tend to have not only smaller populations but fewer tasks as well. Icelandic local governments account for roughly one third of government consumption, whereas the Scandinavian average is closer to two thirds. (Kristinsson, 2002) The Scandinavian systems, of course, run two layers of local governments (where the units at the secondary level are often about the size of the Icelandic population), but even when compared to the primary level in Scandinavia the share of Icelandic local governments seems low. Primary education is the most important of local government tasks in Iceland but others include various social services, local planning, environmental affairs, youth, culture and various other areas of public services. Local governments in Iceland, however, play a relatively small role in health, further education and policing to name a few areas.

The need for larger local government units is widely accepted in Iceland and governments since the early 1990s have given local governments various incentives to unite with the result that the number of units has been reduced by more than half. At the same time, governments have remained committed to a policy of voluntary unifications and the law prohibits forced unification except in extreme cases (less than 50 inhabitants for three years in a row).

The benefits of larger local government units according to government policy papers have to do with synergy, economies of scale and accountability. Larger local governments will have greater capacity to produce services and a stronger financial basis than the smaller ones. (Félagsmálaráðu-neytið 2005) They will in many cases also be more directly accountable, replacing (as they will in many cases) co-operative networks where the relationship between election results in individual communes and the policy results in a co-operative network are often less than clear. (Félagsmálaráðu-neytið 1991) At the same time it is recognised in the more recent policy statements that there may be adversary effects of creating larger local units, including more distant services, a

\footnotetext{
${ }^{1}$ A list of local governments and their population size may be obtained through the home page of the Association of local authorities in Iceland at www.samband.is
} 
weaker feeling of policy influence in the communities and the creation of marginalised areas within the new and enlarged units. (Félagsmálaráðuneytið 2005) This is in accordance with the results of recent research on the impact of local government amalgamations on the local population. (Eypórsson \& Jóhannesson 2002)

Local government reform in Iceland is motivated primarily by management considerations. Although local participation is clearly among the main justifications for local governments in general scant attention has been paid to the effects of amalgamations on participation. In what follows we try to establish if participation is important and, if so, which forms are important and how.

\section{Responsiveness}

Local governments may be successful or unsuccessful in many different ways. It is not difficult to imagine a local government which is highly successful in many areas of culture. Its success could be measured in terms of attendance to cultural events and might reflect efforts discernible in its policy priorities, organisation and expenditure. Similarly, a local government might be highly successful at cutting back local government expenditure by economising on local services and cutting taxes. One can even imagine a local government committed to scientific projects of some sort (such as the exploration of space) and able to contribute its small share in that area with relative success.

But to measure the success of local governments as democratic organisations it seems necessary to focus on their responsiveness. Whatever the impact of local government policy in the fields of culture, finance or science may be, this has no necessary relation to its quality as a democratic organisation. There are many different normative theories of democracy, which focus on different aspects of the political process. (Held 1987) Such theories have at least two things in common. One is that they see democracy as a system of governance where the citizenry - either directly or indirectly - exercises some measure of control over public policy. The other is that policy decisions affect policy outcomes in some meaningful manner. ${ }^{2}$

The problem is, of course, finding a useful indicator of responsiveness. Kjær and Mouritzen (2003) maintain that "satisfaction is an indicator of responsiveness given an assumption that if the communes manage to obtain the wishes and demands of the citizens and transform them into political decisions, this will affect their level of satisfaction". (2003 p. 25) Other things being equal, a responsive political system produces policy outcomes which are approved of by

\footnotetext{
${ }^{2}$ It is of course conceivable that democratic procedures bear no relation whatsoever to policy outcomes, in which case democracy would be difficult to defend (as opposed to anarchy, elitism or other alternatives to democracy). But insofar as theories of democracy are partly normative in nature - they regard democracy as a desirable system of government they need to assume that democracy positively affects policy outcomes.
} 
the citizenry. If a democratic government tries to act otherwise the corrective mechanisms of democracy will intervene to put the government on the right track again. Thus, citizen satisfaction may be used as an indicator of how well government is responding to the needs of the citizens.

Citizen satisfaction with local governments in Iceland was measured in a national survey with a random sample from the national register. ${ }^{3}$ Respondents were asked how satisfied they were with local government services, both in general and in particular areas.

Table 1. Citizen satisfaction with local government services in Iceland (\%)

$\begin{array}{llll}\begin{array}{l}\text { Very } \\ \text { pleased }\end{array} & \begin{array}{l}\text { Rather } \\ \text { pleased }\end{array} & \text { Neutral } & \begin{array}{l}\text { Rather Very Total } \\ \text { dissatisf. dissatisf. }\end{array}\end{array}$

$\begin{array}{llllrrrr}\text { Services in general } & 10 & 46 & 32 & 9 & 4 & 100 & 1339 \\ \text { Education } & 19 & 47 & 13 & 15 & 6 & 100 & 1199 \\ \text { Social services } & 14 & 47 & 20 & 14 & 5 & 100 & 1240 \\ \text { Planning and construction } & 10 & 40 & 19 & 21 & 10 & 100 & 1248\end{array}$

Far too Rather About Rather Far too high

low too low right too high

$\begin{array}{llllllll}\text { Local govt. taxes } & 0 & 2 & 63 & 22 & 12 & 100 & 1326\end{array}$

Data from local government survey carried out in 2000. The question was "Are you generally satisfied, neutral or dissatisfied with the services of the commune?(probe: very or rather). Similar questions were used on education, social services and planning and construction. The question on taxes was: "Do you think the taxes and fees levied by the local government are too high, about right or too low? (probe: far too or rather too...).

Respondents seem to be rather favourably disposed to their local governments. Only 13\% are dissatisfied with services in general and between 19-36\% in the areas of education, social services and planning and construction. A certain correlation exists between satisfaction from one area to another, but not so strong as to indicate that respondent don't discriminate between local govern-ment services in the different fields. ${ }^{4}$

\footnotetext{
${ }^{3}$ The survey was carried out in April 2000 based on a national random sample of 1500 respondents and an addition sample of 500 from communes with fewer than 2500 inhabitants. For more detail, see Kristinsson 2002.

${ }^{4}$ The correlation ( $\mathrm{r}$ ) between satsifaction in general with education is $.28^{* *}$, with social services it is $.36^{* *}$ and with planning and construction it is .34**. The lowest correlation is between education and planning, .24**.
} 
Using citizen satisfaction as an indicator of responsiveness invites the criticism that satisfaction may be affected by other things besides democratic responsiveness. Thus, it could be argued that government capacity - rather than responsiveness - explains the level of satisfaction, or even that some other mechanism (such as competition between local governments) is sufficient to ensure responsiveness, which would make democracy a superfluous part of our explanation of satisfaction.

Government capacity at the local level in Iceland varies a great deal. Some of the local governments in Iceland have no full time employees in their central offices and in others a single manager takes care of more or less all tasks. The largest ones on the other hand have access to a relatively large stock of specialists and professionals. Local government capacity, according to Dahl and Tufte, is the function of size. (Dahl \& Tufte 1974) Very small governments are weak on capacity while the larger ones are strong. Some doubt exists as to how far the relationship between size and capacity holds and at which point the diseconomies of scale begin to intervene. (Mouritzen 1991) In the Icelandic case, however, it is beyond dispute that size is an important factor in the capacity of local governments to provide services, even if its effects are to some extent offset by other factors, e.g. local government transfers.

On the other hand there is hardly any general relationship between size and citizen satisfaction. Various attempts to establish such a pattern for the whole range of local governments or within different size categories have failed to establish such a relationship. (Kristinsson 2002)

\section{Table 2. Citizen satisfaction according to size: \% satisfied or very satisfied with services}

$\begin{gathered}\text { Inhabitants } \\ 1-999\end{gathered} 1000-9999 \quad 10.000-26.000 \quad$ Reykjavik (115.000)

\begin{tabular}{|c|c|c|c|c|}
\hline Services in general & 52.8 & 60.9 & 59.6 & 48.4 \\
\hline Education & 75.8 & 70.2 & 75.5 & 52.4 \\
\hline Social services & 61.8 & 62.9 & 69.2 & 52.4 \\
\hline Planning and const & n54.2 & 58.9 & 60.6 & 38.6 \\
\hline Total & 100 & 100 & 100 & 100 \\
\hline $\mathrm{N}$ & 288 & 447 & 245 & 391 \\
\hline
\end{tabular}

Local government survey 2000. Correlations between satisfaction and size are slightly negative if Reykjavik is included $\left(\mathrm{r}=-.12^{* *}\right.$ for services in general, $-.20^{*}$ for education, $-.10^{* *}$ for social services and $-.15^{* *}$ in planning and construction. If, however, Reykjavik is excluded the correlations change to $.07^{* *}, .03, .08^{* *}$ and $.05^{*}$.

The major finding is that the citizens of Reykjavik are much less satisfied with the services they are receiving than the inhabitants of other localities. Reykjavik fares much worse than the other communes in the Reykjavik area, 
despite the fact that in quantitative terms it provides the most extensive and professionalized services in the country in most respects. In fact, it is slightly astonishing that the inhabitants of the smallest communities, many of whom receive no social services at all from their local government, claim to be much more satisfied with the services provided by the commune than the inhabitants of Reykjavik. The citizens seem to take into account the different capacities of their local governments when rating their services.

Apart from Reykjavik, size appears to make very little difference to the satisfaction of the inhabitants. There is a weak relationship to the effect that the inhabitants of larger communes (excluding Reykjavik) express greater satisfaction with regard to services in general and social services, but in terms of explained variance the relationship is in fact next to non-existent. While in terms of expertise, professional staff and facilities the capacity of the smallest local governments is undoubtedly smaller than that of the larger ones, this appears to have little to no effects on the satisfaction of the inhabitants.

A different interpretation of citizen satisfaction could be that local governments respond to inter-governmental competition along the lines described by Tiebout (1956) rather than to democratic pressures. Local governments should offer different combinations of taxes and services to attract different categories of inhabitants. In actual fact, however, the local governments have very little scope for offering different tax rates and an analysis of the reasons why people move between communities indicates that the services of local government in fact play only a very minor role. (Kristinsson 2002: 58-61) Thus, it seems unlikely that a Tiebout-type market actually exists at the local level in Iceland.

Reykjavik presents a problem in the analysis of citizen satisfaction in Iceland. It is an outlying value in terms of size while respondents there tend to be rather more critical of local government services than the national average. In most of the analysis below - where this factor could unduly influence the results Reykjavik is therefore excluded from the analysis. The puzzle of why the inhabitants of Reykjavik are less satisfied than those of other communes (including those in the larger Reykjavik area) is not among the tasks of the present paper, although our analysis would lead us to suspect that greater distance from the citizenry may be an important factor.

\section{Electoral competition and satisfaction}

The minimalist school of democratic theory defines democracy simply as "that institutional arrangement for arriving at political decisions in which individuals acquire the power to decide by means of a competitive struggle for the people's vote". (Schumpeter 1976: 269) The role of the electorate in this theory is exclusively to choose a government in a fair election and evicting it when necessary. The threat of eviction ensures sufficient responsiveness on behalf of the government and makes it behave in a manner consistent with the goal of 
winning elections. No participation is called for in the general public apart from turning out at election time.

In drawing the outlines of a democratic system, Schumpeter clearly has single party majorities in mind. The "primary function of the elector's vote is to produce government" and "producing government practically amounts to deciding who the leading man shall be ... we shall call him Prime Minister". (Schumpeter 1976: 273) In coalition systems the relationship between election results and government formation is much less direct. Parties, however, clearly believe that their chances of assuming a governmental position are - broadly speaking - a function of their electoral performance. Hence, we can assume that in a coalition system, as well, the electoral mechanism should encourage responsiveness in government.

In the smallest Icelandic communes it quite frequently happens that no lists or candidates emerge at all before an election. In such cases the election takes place nonetheless but is open in the sense that each elector can write down the names of any of his or her neighbours and those who receive the greatest number of votes are obliged to serve in the local council for the next four years. These elections are non-competitive in that no-one is actually running. They deviate from Schumpeter's assumption that there are candidates willing to compete for office. If the element of competition is what keeps power-holders responsive to the electorate we would expect power holders in such small communes to be less responsive - according to Schumpeter's theory - since they are not willing to run for office at all

The data seems not to support Schumpeter's thesis. In table 3 we examine the satisfaction of citizens according to whether competition takes place in elections or not.

Table 3. Share of respondents satisfied with local government in general by electoral competition $(\%)$

No Competition

competition

$\begin{array}{lll}\% \text { satisfied } & 64 \% & 60 \%\end{array}$

$\begin{array}{lll}\text { Others } & 36 \% & 40 \%\end{array}$

$\begin{array}{lll}\text { TOTAL } & 100 \% & 100 \%\end{array}$

$\mathrm{N}=\quad 93 \quad 1278$

Local government survey 2000. Reykjavik excluded. "Others" includes those who are either indifferent or dissatisfied.

Basically it makes very little difference to the satisfaction of the inhabitants if elections are competitive or not. To the extent there is a difference it is actually in favour of the communes where there is no competition, although given the 
small number of respondents in that category too much should not be made of the difference.

Undoubtedly, the electoral mechanism is an important part of any realistic conception of democracy in the modern world. But according to this the crucial factor is not the existence of a political entrepreneur, willing to compete for office. To further test the effects of competition on citizen satisfaction we tried to construct an index of competitiveness to measure the core of Schumpeter's meaning of the term. The index is accounted for in Appendix 1. The index takes into account the two-partyness of competition on the one hand and the closeness of the race on the other. The result of this experiment was a very slight, but statistically significant, correlation of $r=-.13^{* *}$. When Reykjavik is excluded the correlation goes down to $r=-.05^{*}$. To the extent that competition matters - which is not a great deal - it has the effect of reducing satisfaction. Like our previous finding, this gives no support for the minimalist theory.

This may be interpreted in various ways. One is that Schumpeter's conception of democracy is too narrow. It is not merely the existence of the political entrepreneur which is crucial but a whole range of opportunities for participation, equal voting rights and information which is the crucial factor (Dahl 2000: 38), irrespective of the emergence of a political entrepreneur. While this is probably true these factors will probably not go a long way explaining variations in satisfaction with Icelandic local governments, given that they are basically similar across the country. Another possibility is that actual participation in between formal elections is an important mechanism for ensuring the responsiveness of the system.

\section{Party-democracy and satisfaction}

A second model of democracy, implicit in the works of many European scholars and party reformers in the United States may be termed "party democracy". The term is borrowed from Wright (1971) and refers the idea that the deficiencies of electoral markets are partly or wholly compensated for by internally democratic party organisations. Mass parties, in this view, recruit a large number of activists whose voices guide the party leadership, which essentially is dependent on the membership - rather than the electorate directly - for its position.

Some doubts remain as to the realism of party democracy and the theory has been dealt several blows since Michels (1962 - originally 1915) and onwards. Nonetheless, it remains a major underpinning for the legitimacy of most European party organisations. The legitimacy of party organisation is an important factor for the workability of parliamentary democracy, which is - as Strøm puts it - "the world's most popular political project". (Strøm 2000: 261) Parliamentary government is party government. While parliamentary government can clearly work without internally democratic parties - such as it did in the early days of caucus parties and lax party discipline - the greater legitimacy 
of democratic organisations was a central element in the spread of the mass party during the Twentieth century. (Duverger 1964)

The Icelandic parties have always been weak membership organisations. Certainly a fairly large proportion of the electorate reports membership of one of the political parties $(17 \%)$ but this is partly because the difference between formal membership and subjective membership is not clearly defined. The membership files of the parties are wildly inaccurate (Hardarson 1999) and someone who at one point has joined a party as a youngster or to participate in a primary election is likely to remain there for decades even if paying no attention to the party in any respect during that time.

The organisational strength of the political parties varies to some extent from one locality to another. In many places there are no party organisations whereas in others the national party system is more or less fully duplicated. Individual party members can still exist in such places, but they belong to party branches which do not match their local government.

In the theory of party democracy there are a number of testable assumptions, including the following, which are central to the theory:

a) clear party alternatives encourage participation

b) the existence of party organisations creates a sense of being able to influence decisions

c) the existence of party organisation leads to greater responsiveness

\section{a) Clear party alternatives make a difference}

Clear party alternatives can in theory emerge for any number of reasons and they need not be based on democratic organisations. Totalitarian parties, for example, do not necessarily value internal democracy but they obviously make for pretty clear alternatives during elections. It is a minimum requirement, nonetheless, for party democracy, that parties propose relatively clear platforms to attract activists. Without clear party platforms the mass of party supporters would not find it worth their while to engage in politics and hence party democracy would collapse. (Wright 1971)

A basic requirement for clear party alternatives (although not a sufficient one) is that candidates are put forward. As already mentioned, a large number of local government elections in Iceland are non-competitive in the sense that no lists emerge (or in a few cases only one). This happens above all in the smallest communes and even if this is quite common in the smallest ones the number of respondents is too small to invite a detailed analysis. The indications are, as noted in table 3, however, that the satisfaction of respondents is about the same with their local governments as where elections are competitive.

The finding that competitive elections do not lead to greater satisfaction with local governments does not necessarily mean that the nature of alternatives at local elections makes no difference at all. In actual fact, the nature of electoral competition matters a great deal with regard to turnout, especially when we 
control for size. Where there are lists, turnout tends to be much higher than where there are no lists.

\section{Table 4. Average turnout in local government elections (\%)}

Type of election:

$\begin{array}{lll}\text { Lists } & \text { No lists } & \begin{array}{l}\text { Number of } \\ \text { localities }\end{array}\end{array}$

$\begin{array}{llll}\text { Less than } 100 & -76 \% & 22 & \\ 100-499 & 90 \% & 75 \% & 52 \\ 500-1999 & 89 \% & 70 \% & 29 \\ 2000-9999 & 83 \% & -14 & \\ 10 \text { thousand or more } & 80 \% & -5 & \end{array}$

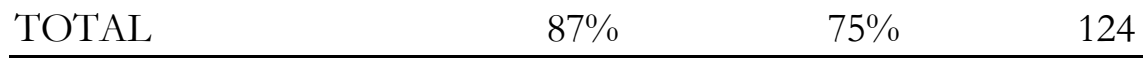

Data from election in 1998. The election of 1998 is used rather than that of 2002 to demonstrate the point on account of a lager number of very small communes. The correlation of inhabitants with turnout where there were lists is $r=-.31$ but -.25 where there are no lists. The relationship between inhabitants and participation disappears when communes are not divided according to election mode $(\mathrm{r}=.02)$.

The nature of alternatives matters a great deal. Where the alternatives are clear, turnout tends to be higher than where they are less so. In the communes with less than two thousand inhabitants turnout is around $90 \%$ where lists emerge but less than $75 \%$ where there are no lists. The emergence of clear alternatives in elections thus seems to heighten the popular interest. This finding is consistent with the theory of party democracy.

\section{b) The existence of party organisations creates a sense of being able to influence decisions}

Insofar as party democracy is not only a theory of party organisation but of democracy it would have to be shown that party organisations actually work as channels of access to political influence for the party membership. Thus, we would expect the existence of party organisations in a commune to increase the sense, among the members of a community, of being able to influence decisions.

Party organisations seldom thrive in the very smallest communes. Out of 20 communes with less than 100 inhabitants in the year 2000 none had party organisations and out of 69 communes with less than 500 inhabitants only 12 had party organisations. 


\section{Table 5. Number of communes where party organisations exist - don't exist by size (absolute numbers)}

Inhabitants

$$
0-1599 \quad 1600-4999 \quad 5000 \text { or more }
$$

No party branches

71

17

1-2 parties with branches

Replica of national

party system

Total

$\%$ of respondents members

of political parties

$21 \%$
0

0

9

9

Data from 2000. Information on the existence of local party organisations was obtained from official party sources and by asking local government managers to estimate which parties led an organised existence in the commune. More than one branch per party can be found only in Reykjavik if separate youth and women's organisations are excluded.

The total absence of party organisations is fairly common up to around 1500 inhabitants but in larger communes there exist in all cases at least some branches of the national party organisations. After the mark of five thousand inhabitants has been reached the local organisational complex more or less replicates the national party system with three or four of the national parties having a local branch. At the same time is seems clear that in the larger communes - above 5000 inhabitants - a smaller proportion of the electorate participates in the political parties and this proportion is similar for the smaller communes in this categories and Reykjavik (with 15\% party members) is basically similar to most of the others in this respect). Above the mark of around five thousand inhabitants, party membership seems to fall. In fact, as the parties get better organised, they seem to lose some of their recruitment potential.

In table 6 we look at the number of respondents who feel they are able to influence the decisions of their local governments. They are divided into party members and non-members and by whether they live in places where party organisations exist or not. 
Table 6. Sense of being able to influence decisions of local governments: $\%$ who think they could make an impact

\author{
Party members $\quad$ Non-members
}

\begin{tabular}{lcc} 
Party org. exist & $50 \%$ & $31 \%$ \\
Party org. non-existent & $36 \%$ & $24 \%$ \\
N & 197 & 678 \\
\hline
\end{tabular}

Local government survey 2000. Reykjavik excluded. Based on the following question: Do you think it likely or unlikely that you could influence decisions of the commune, if you tried?

Generally party members have a greater sense of being able to make an impact. Similarly the sense of being able to influence local government decisions is stronger where party organisations exist both among party members and non-members. This finding is in line with what the theory of party democracy would predict.

\title{
c) The existence of party organisation leads to greater responsiveness in local government
}

If party democracy works to increase the responsiveness of local governments we must not only show that the presence of party organisations creates a sense of being able to make an impact but also that actual satisfaction with the services of local government increases. Table 7 shows satisfaction with services where party organisations exist and where they don't.

Table 7. Satisfied with services of local government according to whether party organisations exist (\%)

$$
\begin{gathered}
\text { Party organisations } \\
\text { exist }
\end{gathered}
$$

Satisfied

Others

Total $\mathrm{N}$
$61 \%$

$39 \%$

$100 \%$

1128
Party organisations non-existent

$$
\begin{array}{r}
48 \% \\
52 \% \\
100 \% \\
248 \\
\hline
\end{array}
$$

Local government survey 2000. Reykjavik excluded. Others include neutrals and dissatisfied

Table 7 lends some support to the theory that party organisations make local governments more responsive. Where party organisations exist $61 \%$ of respondents claim to be satisfied while the corresponding figure where party organisations are non-existent is $48 \%$. The question is, however, if the existence of party organisations makes local governments more responsive to the electorate in general or only to party members. It is quite possible that party organisations articulate the needs and interests of their own members without 
making local governments any more responsive to the population at large. The results in table 7 could be consistent with such a pattern.

Party members in general tend to be much more satisfied with the services of local governments than others. They have better access, they are better informed and they tend to be better integrated into the local polity. Almost three out of four $(73 \%)$ members of the political parties outside Reykjavik are satisfied with the services of their local government in general compared to $57 \%$ of non-members. ${ }^{5}$

Table 8. Satisfaction with local government among party members and non-members according to whether party organisations exist or not. Table shows \% satisfied.

\begin{tabular}{clll} 
& Party members & Non-members & All \\
Party org. exist & $80 \%$ & $53 \%$ & $61 \%$ \\
Party org. non-existent & $(65 \%)^{*}$ & $52 \%$ & $48 \%$ \\
N & 146 & 697 & 843 \\
\hline
\end{tabular}

Local government survey 2000. Reykjavik excluded.

* Note few respondents: $\mathrm{N}$ where party organisations are non existent is 131 , of which only 15 are party members.

It seems clear that the existence of party organisations does not increase the satisfaction among non-members with their local government. The increase in overall satisfaction where party organisations exist stems only from the greater satisfaction of party members. Non-members are not affected - neither positively nor negatively - by the existence of party organisations. Thus, if a large proportion of the electorate can be mobilised into political parties this might make party democracy significantly more responsive than systems where party organisations have no mobilising function.

\section{Direct and participatory democracy}

Modern participatory schools of democracy may be regarded as a reaction against the imperfections of electoral markets and party democracy, although historically, of course, direct democracy claims a much longer ancestry than either of the other schools. Participatory theorists also have a broader view of the purpose of democracy: its value lies not merely in bringing greater responsiveness about but also in its impact on the development of individuals and communities.

Advocates of participatory democracy tend to see it as a corollary of the representative system rather than its replacement. "We must rely," as Macpher-

\footnotetext{
${ }^{5}$ The corresponding figure for Reykjavik are: party members, 53\% satisfied; non-members $47 \%$ satisfied.
} 
son puts it "though we need not rely exclusively, on indirect democracy." (1977: 97) Given that participatory democracy covers a rather heterogeneous set of ideas - from Rousseau to Pateman - it is not easy to derive hypotheses from the theory which all theorists would necessarily subscribe to. The following, nonetheless, is an attempt to capture some of the basic themes:

a) Activists are better informed than non-activists

b) Activists are more satisfied than non-activists

c) Activism is equally likely in large units as in small units

d) Purely local parties are more responsive than national parties

e) Activists are a fairly representative group in socio-economic terms

\section{a) Activists better informed than non-activists?}

Most theories of participatory democracy see participation as a way of developing individual political understanding and skills. (Pateman 1970) The citizens learn through participation and become more knowledgeable in the process: hence better citizens. A fairly large proportion of the citizenry in Icelandic communes has tried to influence local government. About 53\% claim to have tried to influence their local government at one point or another. The most common form of activity is the signing of a petition, which $34 \%$ have done. $26 \%$ have spoken to council members, $20 \%$ attended meetings, $12 \%$ joined associations, and $6 \%$ written letters to the press and $14 \%$ mention various other activities.

In line with this we should expect activists generally to be more knowledgeable about politics than non-activists. Political knowledge was tested by asking respondents to name up to three members of their local government council. Almost 60\% were able to correctly identify at least one member, and a fairly high proportion of these could actually name three $(48 \%)$.

The data indicates a clear relationship between activism and political knowledge. 


\section{Table 9. Activism and knowledge: \% who could name at least one politician}

Activity:

Attending a meeting

Name at least one

Speaking to council members

Name at least one

Joining an association

Name at least one

Writing to the press

Name at least one

Signing a petition

Name at least one
Active

$83 \%$

$82 \%$

$86 \%$

$78 \%$

$70 \%$ $\underline{\text { Not active }}$

$53 \%$

$52 \%$

$57 \%$

$60 \%$

$57 \%$

Local government survey 2000. Reykjavik is included in order to obtain sufficiently many respondents. The same overall pattern is maintained also, however, when Reykjavik is excluded. $\mathrm{N}$ in the first column (down) is $318,380,169,78$ and 433 . In the second column it is $972,911,1118,1211$ and 856 .

On the whole, the chances of those who are inactive in local government being able to name a local council member are between $53-60 \%$. The odds improve substantially with activity in local government and especially among those who have joined associations, attended meetings or spoken to council members. Between $82-86 \%$ of those can name at least one member of the local council. This indicates that the activists are better informed in local government matters than those who are not active. These results are consistent with the predictions of participatory theories of democracy

\section{b) Activists more satisfied than non activists?}

If the democratic process makes governments responsive to citizen activity it should follow that there is some relationship between citizen activity and their satisfaction with government. Active citizens where government is responsive to activism should be more satisfied with the government than others. Nonactivists should be less so

There are of course different types of citizen activities and all of them need not be equally likely to increase citizen satisfaction to the same extent. The relationship between different forms of activity and satisfaction with local government is shown in table 10 . 


\title{
Table 10. Satisfaction with local government by activity: \% satisfied
}

\author{
Active Non-active
}

Attending a meeting

Satisfied $\quad 65 \% \quad 53 \%$

Speaking to council

members

Satisfied $\quad 63 \% \quad 53 \%$

Joining an association

$\begin{array}{lll}\text { Satisfied } & 69 \% & 54 \%\end{array}$

Writing to the press

$\begin{array}{lll}\text { Satisfied } & 66 \% & 55 \%\end{array}$

Signing a petition

Satisfied

$53 \% \quad 57 \%$

Local government survey 2000. As in table 9, Reykjavik is included to increase the number of respondents but the same overall pattern emerges also when Reykjavik is excluded.

Table 10 seems to support the claim that activism in general leads to increasing satisfaction with the performance of local governments. Around two out of three of those who at some point have been active are satisfied with the performance of their local government compared to just over half of the nonactive respondents. The only exception to this pattern is the signing of petitions where we get the reverse pattern: those who have signed are marginally less satisfied than those who have signed. Signing a petition, of course, is the most effortless and least demanding of the different activity forms and is generally less connected with civility and social virtue than other forms of participation. (Kristinsson, 2002) It may not be as "serious" a form of participation at the others. But the fact that those who sign are not only randomly similar to the others but slightly less satisfied may also indicate that signatures are typically protest behaviour by disaffected citizens (rather than attempts to positively influence the local government).

The relationship between activism and satisfaction holds even when controlling for socio-economic status. There is no relationship between socioeconomic status and satisfaction in the Icelandic communes.

\section{c) Activism equally likely in large units as in small units?}

A major justification for representative democracy - as opposed to the direct variant - has to do with size and complexity. With increasing size and complexity the idea of the ordinary citizenry taking an active party in the everyday running of the political system becomes more unrealistic. (Dahl 2000)

This is clearly a crucial problem for theories of direct democracy. Modern societies are too large and complex for substantial involvement by the citizenry in anything but the most basic matters (and even in such issues the level of participation e.g. in referendums in Switzerland is not all that promising). Thus, 
we maintain, it would strengthen the theory of participatory democracy if the hypothesised relationship between size and inactivity could be proven false. A different result (namely a strong inverse relationship between size and activism) may not be fatal to the theory but obviously poses a problem.

In table 11 we look at the relationship between activity and size in Iceland.

\section{Table 11. Proportion of voters who have tried to influence their local authorities (\%)}

$\begin{array}{llll}\text { Inhabitants: } & & & \\ \text { Less than } & 1.000- & 10.000- & \text { Reykjavik } \\ \text { one thousand } & 9.999 & 25.000 & (115.000)\end{array}$

\begin{tabular}{lclll} 
Attending a meeting & 40 & 24 & 18 & 15 \\
$\begin{array}{l}\text { Speaking to council } \\
\text { members }\end{array}$ & 42 & 34 & 24 & 17 \\
$\begin{array}{l}\text { Joining an association } \\
\text { Writing to the press }\end{array}$ & 17 & 13 & 14 & 9 \\
$\begin{array}{l}\text { Signing a petition } \\
\begin{array}{l}\text { At least one of the } \\
\text { above }\end{array}\end{array}$ & 33 & 6 & 7 & 6 \\
\hline
\end{tabular}

Local government survey 2000. The question asked was: Have you tried to influence decisions in your commune by attending a meeting on local affairs... How about by speaking to council members etc.

The likelihood that people have tried to influence the decisions of their local government clearly caries with size. Almost two out of three in the smallest units have at one point or another tried to influence their local government compared to around half in the largest communes. About the same number, however, have never tried in Reykjavik and the four communes with over ten thousand inhabitants. This indicates that the effects of size are not fully linear in nature although the special nature of signing petitions has to be taken into account. Signing a petition is the only activity more common in Reykjavik than in other places

\section{d) Purely local parties more responsive than national parties?}

Scepticism against representatives has been associated with direct democracy at least since the time of Rousseau. "Who says organization, says oligarchy" Michels (1962: 365) moreover claimed in 1915. National party organisations tend to be large and bureaucratic, often run by professional politicians and professional administrators (although the latter are not many in the Icelandic context). Local parties, on the other hand, are primarily amateurish and might be expected to escape to some extent the oligarchic tendencies of the national party organisations. They should be closer to the ideals of direct democracy, even if they don't conform fully to its strongest claims.

Local lists are quite common in Iceland. They go under a wide variety of names; some more conventional (independents, new force etc.) than others 
(e.g. Krian (the artic stern) Klettur (rock) etc.) In some cases the local lists have an element of some of the established national parties within - one or more but in others they are entirely local inventions. In 2002, 90 out of 182 lists competing in the elections were local lists. Their combined share of the vote nationally was $16.3 \%$ but their average share locally was $21.4 \%{ }^{6}$

\section{Table 12. Citizen satisfaction where national and local parties predominate: \% very or rather satisfied}

\author{
National parties \\ predominant
}

Local parties

predominant

\begin{tabular}{lcl} 
Satisfied & $60 \%$ & $54 \%$ \\
Not satisfied & $40 \%$ & $46 \%$ \\
Total & $100 \%$ & $100 \%$ \\
$\mathrm{~N}$ & 1998 & 151 \\
\hline
\end{tabular}

Local government survey 2000. Reykjavik excluded. National parties predominant where they receive over $50 \%$ of the vote - local parties dominant where national parties below $50 \%$. Based on 1998 election and interview data from 2000.

The data does not support the thesis that national parties reduce responsiveness in local government. If anything, it indicates that they are less responsive, although the difference is perhaps not sufficiently large for an elaborate interpretation along those lines. Clearly it does not make a lot of difference if the lists are placed by branches of the national parties or by local people. This may be because in actual fact the Icelandic parties are loose structures in any case and flexible enough to take on a highly local character in different places. Alternatively the relative strengths and weaknesses of national party branches and local parties may more or less even out on our indicator of responsiveness. Finally it may be a contributing factor that some of the local lists are actually alliances of people from different national parties and hence not as local in nature as might be expected. The current data is insufficient to evaluate these different interpretations.

\section{e) Activists a representative group in socio-economic terms?}

Before a theory of participation can turn into a theory of participatory democracy some good answers must be found to the criticism often directed against participatory democracy (Fiorina 1999) that activists are in fact nonrepresentative and hence likely to divert public decision making away from rather than towards - the majority opinion. Possibly no definitive answer can ever be found to this dilemma. In some cases the activists may be representative while not in others. This does not mean that no overall estimation can

\footnotetext{
${ }^{6}$ Not counting the R-list in Reykjavik which is an alliance of three parties and independents. It received $52.6 \%$ of the Reykjavik vote which amounted to $22.1 \%$ of the national vote.
} 
be obtained concerning how likely the group of activists is to be different from the larger group of non-activists.

To test the impact of socio-economic status we constructed a combined index of local political activity, counting the types of things respondents had done. Out of this we obtained a measure ranging from 0 to 6 ("other activity" is included). The correlation between socio-economic status and activity turns out to be low $\left(\mathrm{r}=.05^{*}\right)^{7}$

Given that Iceland is a fairly egalitarian society we might in fact expect the impact of socio-economic status to be weaker than in many other societies. The educational differences in the population may, however, be more typical of a developed society. Education, as it turns out, tends to increase the propensity for participation much more than socio-economic status. The correlation between education and activism is $\mathrm{r}=16^{* *}$ - and the result is the same irrespective of whether signing a petition is included in the measure of activism or not.

\footnotetext{
${ }^{7}$ When signing a petition is excluded we get a similar result $r=.04 *$.
} 


\section{Table 13. Education and local political activism in Iceland}

Education:

\begin{tabular}{|c|c|c|c|c|}
\hline Activity: & $\begin{array}{l}\text { Elementary } \\
\text { or less }\end{array}$ & $\begin{array}{l}\text { Vocational } \\
\text { educ. for } \\
\text { manual jobs }\end{array}$ & $\begin{array}{c}\text { Commercial } \\
\text { and general } \\
\text { education }\end{array}$ & $\begin{array}{l}\text { University } \\
\text { education }\end{array}$ \\
\hline $\begin{array}{l}\text { Attended a meeting } \\
\text { Not attended }\end{array}$ & $\begin{array}{r}16 \\
\underline{84} \\
100\end{array}$ & $\begin{array}{r}20 \\
\underline{80} \\
100\end{array}$ & $\begin{array}{r}23 \\
\underline{77} \\
100\end{array}$ & $\begin{array}{r}32 \\
\underline{68} \\
100\end{array}$ \\
\hline $\begin{array}{l}\text { Spoken to council mbrs. } \\
\text { Not spoken to.... }\end{array}$ & $\begin{array}{r}19 \\
\underline{81} \\
100\end{array}$ & $\begin{array}{r}30 \\
\underline{70} \\
100\end{array}$ & $\begin{array}{r}33 \\
\underline{73} \\
100\end{array}$ & $\begin{array}{r}37 \\
\underline{63} \\
100\end{array}$ \\
\hline $\begin{array}{l}\text { Joined an association } \\
\text { Not joined }\end{array}$ & $\begin{array}{r}7 \\
93 \\
100\end{array}$ & $\begin{array}{r}14 \\
\underline{86} \\
100\end{array}$ & $\begin{array}{r}16 \\
\underline{84} \\
100\end{array}$ & $\begin{array}{r}18 \\
\underline{82} \\
100\end{array}$ \\
\hline $\begin{array}{l}\text { Written to the press } \\
\text { Not written }\end{array}$ & $\begin{array}{r}5 \\
\frac{95}{100}\end{array}$ & $\begin{array}{r}4 \\
\underline{96} \\
100\end{array}$ & $\begin{array}{r}4 \\
\underline{96} \\
100\end{array}$ & $\begin{array}{r}13 \\
\frac{87}{100}\end{array}$ \\
\hline $\begin{array}{l}\text { Signed a petition } \\
\text { Not signed }\end{array}$ & $\begin{array}{r}32 \\
\underline{68} \\
100\end{array}$ & $\begin{array}{r}32 \\
68 \\
100\end{array}$ & $\begin{array}{r}32 \\
68 \\
100\end{array}$ & $\begin{array}{r}41 \\
\underline{59} \\
100\end{array}$ \\
\hline $\mathrm{N}$ & 554 & 358 & 241 & 201 \\
\hline
\end{tabular}

Local government survey 2000.

Those with more education are clearly more likely to take part in all of the activities mentioned above. Those with university education are - with the single exception of signing a petition - about two or three times as likely to have made use of the activity in question than those with elementary education or less. They are also more likely to sign petitions than other groups but the difference is not as great.

These results pose a problem for participatory theories of democracy. While participation may have all kinds of benign results for the development of individual political skills, civic virtue and social capital there is reason to doubt the representatitveness of the activists in local politics. This can mean that when they are given disproportionate influence over decision making the results will not reflect the majority of opinion but be systematically biased in favour of particular groups. 


\section{Conclusion}

The analysis of participation in Icelandic local governments indicates the following:

In the first place, no relationship was found between competitive elections and the satisfaction of the citizenry. The mere fact that electoral competition takes place seems not to increase citizen satisfaction as one would expect if elections were the only mechanisms ensuring democratic responsiveness in elections.

The presence of political parties, on the other hand, tended to have a positive effect on responsiveness. The data does not support the view that political parties somehow bias public decision making to the disadvantage of non-members. Non-party members were equally satisfied with local governments where party organisations existed as they were where they were nonexistent. Similarly, the presence of purely local parties (as opposed to national parties) seems not to make local governments any more responsive than where the national parties predominate. It seems clear, however, that the increased satisfaction with local government where party organisations are active stems only from the increased satisfaction of party members. Non-party members are no more satisfied where party organisations are present than where they are absent.

Thirdly it seems clear that participation increases the political knowledge and satisfaction of the citizenry with local government. This applies at least to those attending meetings, speaking to council members and joining associations to influence local governments. Signing petitions, however, seems not to have a positive impact. From the point of view of local government, activism has a positive impact on the evaluation of local government performance.

Activism seems more easily encouraged in smaller units than in larger ones. This is largely in line with those arguments for representative democracy (as opposed to participatory or direct democracy) which emphasize the relationship between increasing size and complexity and lack of public participation. Similarly, it was found that the activists are not a representative group of people, at least with regard to education, and opening up channels for activism may in fact be the source of a certain amount of bias in public decision making.

The dilemma for local governments is how to reap the undoubted benefits of increasing participation without endangering the representativeness of decision making. In the Icelandic context, stronger party organisations and holding on to small communes might seem the obvious answer. The problem is that both party organisations and small communes are fighting an uphill struggle. Party membership has nowhere - as far as can be seen - been increasing in recent years in developed democracies, even if the decline in membership rates is progressing at different rates. Similarly, the small communes in Iceland are under pressure to amalgamate in order to produce larger units with greater capacity. 
Hence, the communes are likely to seek ways of involving the citizenry to an increasing extent through various non-conventional mechanisms. Two approaches seem possible. One is to concentrate on bringing services closer to the people, like Reykjavik has done to a certain extent (neighbourhood services, web based solutions). This does not really open up new channels of influence and may thus not increase the democratic responsiveness of the system in the sense discussed here. Another is to open up user influence and neighbourhood controls in various spheres of local government activity. This could increase the responsiveness of the system to those active in local government politics but runs their risk of creating a bias in favour of non-representative groups of activists. The risks involved can, however, to some extent be calculated and to some extent possibly be held in check by a proper system of checks and balances between the conventional institutions of representative democracy and those of participation. 


\section{Appendix 1}

Various attempts have been made to operationalize competition in a two party context. These can involve a focus on the closeness of the race (difference between first-party and second party results) and the number of uncontested seats, to take two examples. (Danziger, quoted by Boyne 1998, 78). Neither measure, however, is particularly well suited for measuring competitiveness where the list system of proportional representation is being used in a multiparty context in local government. In the Icelandic case, the formation of majorities is usually the result of inter-party bargaining, since single party majorities are relatively rare.

One way to approach this problem is to adopt an indirect measure of competition, such as electoral participation. Rational models of electoral competition would certainly predict that electoral participation should be a function of competitiveness in elections, i.e. probability of each individual voter contributing significantly to the ideological outcome. (Indridason 2004)

A different approach would be to regard two party competition with the parties running neck and neck as the ideal competitive situation and measure deviations from that. Such a measure would have to take into account on the one hand the two-partyness of electoral competition and on the other the lead of the first party.

We adopt the following measure of two partyness:

two-partyness $=$ second party share of votes $/ 1$ - first party share of votes

The measure may be interpreted as the share of the second largest party of the combined non first party vote. Where only one party competes the measure yields 0 while if the second party receives all the non-first-party vote the outcome is 1 .

Our measure of first party lead is the following:

first party lead $=1-$ (first party share of votes - second party share of votes)

Here a very close race between the first and the second party will yield results close to 1 while a large lead for the first party will give much lower results.

Our composite measurement of competitiveness in the sense of a close two party race is the following:

Index of competition $=$ two-partyness $*$ first party lead 
Stjórnmál og stjórnsýsla veftímarit

Here a result of 1 or close to 1 means that the election is contested by two equal parties (e.g. 50/50). Non-contested elections, however, lead to 0 and elections where many equal parties compete will generally give low results. 


\section{Bibliography}

Association of local authorities in Iceland homepage, www.samband.is, visited July 2nd 2005.

Boyne, G. A. 1998. Public Choice Theory and Local Government (Houndsmills, Basingstoke: Palgrave)

Dahl, R. 1956. A Preface to Democratic Theory (Chicago: The University of Chicago Press)

Dahl, R. \& E. Tufte 1973. Size and Democracy (Stanford: Stanford University Press)

Dahl, R. 2000. On Democracy (New Haven: Yale University Press)

Dalton R. 2002. Citizen Politics (New York: Chatham House)

Duverger, M. 1964 (3rd ed.). Political Parties (London: Methuen)

Eythórsson, G. T. 1998. Kommunindelningspolitik i Island (Göteborg: CEFOS)

Epórsson, G. P. and H. Jóhannesson 2002. Sameining sveitarfélaga - áhrif og afleiðingar_(Akureyri: Rannsóknastofnun Háskólans á Akureyri)

Félagsmálaráðuneytið 1991._Skipting landsins i sveitarfélög (Reykjavík: Félagsmálaráðuneytið)

Félagsmálaráðuneytið 2005. Atak um eflingu sveitarstjórnarstigsins. Lokatillögur nefndar um sameiningu sveitarfélaga. (Reykjavík: Félagsmálaráðuneytið).

Fiorina, M. 1999. "Extreme Voices: A Dark Side of Civic Engagement" Skocpol \& Fiorina (eds.): Civic Engagement in American Democracy (Washington: Brookings Inst.) pp. 395-426

Hardarson, O. Th. 1999. "Iceland", World Encyclopaedia of Political Systems and Parties (3rd ed..) (New York: Facts on File).

Held D. 1987. Models of Democracy (Cambridge: Polity Press)

Indridason, I. 2004. "Samkeppni og kosningapátttaka", Ú. Hauksson (ed.) Rannsóknir í félagsvísindum V (Reykjavík: Félagsvísindastofnun-Háskólaútgáfan).

John, P. 2002. Local Governance in Western Europe (London: Sage)

Kjær, U. \& P. E. Mouritzen 2003. "Er der sammenhæng mellem kommunestørrelse og lokalt demokrati?", Kjær \& Mouritzen (eds.) Kommunestorrelse og lokalt demokrati (Odense: Syddansk Universitetsforlag).

Kristinsson, G. H. 2002. Staðbundin stjórnmál (Reykjavík: Háskólaútgáfan)

Macpherson, C. B. 1977. The Life and Times of Liberal Democracy (Oxford: Oxford University Press).

Mair, P 1994: "Party Organizations: From Civil Society to the State", Katz \& Mair (eds.) How Parties Organize (London: Sage)

Michels, R. 1962. Political Parties. A Sociological Study of the Oligarchical Tendencies of Modern Democracy (New York: The Free Press)

Mill, J. S. 1977. "Considerations on Representative Government", Essays on Politics and Society Collected Works of John Stuart Mill vol. XIX (Toronto: University of Toronto Press/Routledge \& Kegan Paul) pp. 371-577.

Mintzberg, H. (1983). Structure in Fives. Designing Effective Organizations (London: Prentice Hall). Mouritzen, P. 1991). Den politiske cyklus (Århus: Politica)

Pateman, C. 1970. Participation and Democratic Theory (Cambridge: Cambridge University Press) Schumpeter, J. 1976. Capitalism, Socialism and Democracy (London: George Allen \& Unwin)

Sharpe, L. 1970. "Theories and Values of Local Government", Political Studies, col. XVIII:2, pp. 153-174.

Strøm, K. 2000. "Delegation and accountability in parliamentary democracies", European Journal of Political Research, 37:3, 261-289

Tiebout, C. 1956. "A Pure Theory of Local Expenditures", Journal of Political Economy, 64, pp. 416-424.

Wright, W. 1971. "Comparative Party Models: Rational-Efficient and Party-Democratic" in W. Wright (ed.) A comparative Study of Party Organization (Columbus, OH: Charles E. Merhill). 